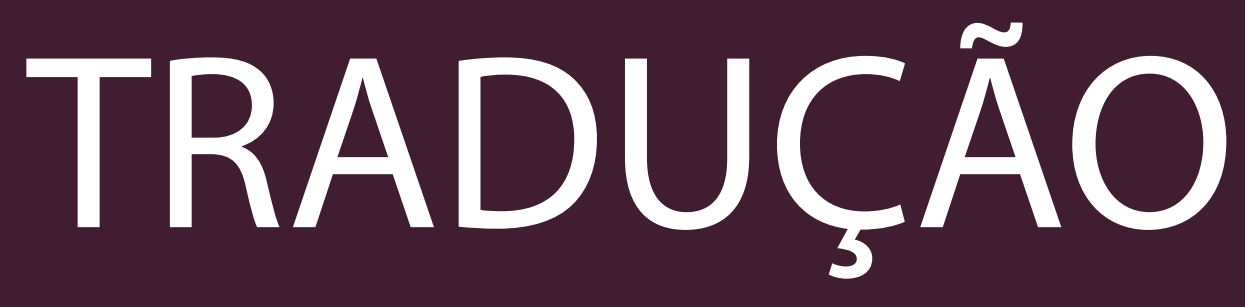





\section{DOIS ENSAIOS DE OMAR PÉREZ}

- OMAR PÉREZ

(Tradução de Pacelli Dias Alves de Sousa')

\section{O INTELECTUAL E O PODER EM CUBA ${ }^{2}$}

1.

bserve o meu passaporte: nos dados pessoais, onde se define "profissão", reza "escritor". Ainda que eu não pretenda imitar o Maiakovski, não posso esquecer o sabor, a euforia daquele poema que aprendemos na escola: sou poeta, sirvo ao poder do povo. Em realidade, limito-me a constatar um fato: a República de Cuba reconhece a minha condição de escritor. Ademais, isso tem dois efeitos secundários. Um, que minha mãe se sente orgulhosa; outro, que os policiais na alfândega me perguntem: "O que você escreve?". "Poesia", respondo. Em certa ocasião, um certo policial foi mais longe. Ocorreu no aeroporto J. F. Kennedy de Nova lorque, algumas semanas depois do 11 de setembro: "Que tipo de poesia?", inquiriu.

- Poesia filosófica.

— O que é poesia filosófica? - insistiu, pondo-me contra a parede. Não lembro o que respondi; não sei o que é poesia, muito menos que coisa é a poesia filosófica, nem tampouco a filosofia, segundo os gregos antigos, a governadora da vida. Nesse ponto de dificuldade, contudo, devo ter respondido satisfatoriamente ante o poder constituído. Não me é ocultado que uma boa parte das verdades são ditas para se sair à francesa. Vocês me perguntarão qual relação há entre ser interrogado por um policial alfandegário de Nova lorque e

[1] Mestre em Língua Espanhola e Literaturas Espanhola e Hispano-Americana na Universidade de São Paulo (USP).

[2] Extraído de Corazón mediterráneo (2010). 
o tema em questão. Em primeiro lugar, o diálogo entre poesia e poder é sempre o mesmo, independentemente da latitude e da circunstância. Em segundo lugar, a situação de um poeta frente ao poder em Cuba não é indiferente à sua situação frente ao poder nos Estados Unidos da América do Norte, e isso que, para um intelectual europeu, por nascimento ou por vocação, possa talvez parecer uma artimanha teórica é, em nossas terras, uma realidade constante há mais de um século. Não se preocupem, dessa vez não vou citar José Martí. Prossigo com o interrogatório:

— Você se chama Omar, é de origem árabe?

- Não que eu saiba.

— Então é muçulmano?

Boa pergunta; no sentido de "abandonado a Deus", seja Deus o que for, somos todos muçulmanos. Não querendo agravar com considerações teológicas minha situação de poeta procedente de uma terra que a própria nação onde eu acabo de aterrizar considera "terrorista", respondi que não.

— Então por que se chama Omar?

- Minha mãe, em homenagem àquele grande poeta, não árabe, mas persa, Omar al-Jayyam, deu-me seu nome.

Persa, árabe ou cubano, ateu ou crente: poeta, sempre suspeito ante o poder constituído. Entretanto, depois de alguns interrogatórios, com o passar do tempo me deixou seguir o meu caminho em paz.

2.

Sempre que regresso a Cuba, volto intensamente à condição política fundamental: a vida diária. Percebo o imperativo de ordenar o discurso político, e poético, não a partir da crítica ao poder constituído, e sim da observação do modo de vida das pessoas, começando pelo meu. Entendo que é essa observação que enaltece o humano como ser e o prepara para modificar a realidade. Sua realidade. Nesse processo, não sou o objeto passivo de algum poder exterior a mim que me diga o que devo observar e como, o que devo modificar e de que maneira. Como poeta, aqui e ali, sou o senhor da minha própria realidade. Ilusão? Romântico? Já o tinha dito Púchkin, que não foi nem impune nem de todo indefeso frente ao poder: o poeta deve ser um pouco estúpido. Mas não é essa estupidez básica, imemorial de humano-poeta que ofusca ou denigre; nela residem ideais, como o sedimento de nossa vida eterna, e esses são eternamente realizáveis.

Agora, o que é, desde a etimologia, a crítica sem crise? Bem-vinda seja essa crise de sistemas, de discursos, de poderes que é, enfim, a crise de uma civilização toda e de seu modelo de consciência. Sem ela, não nos seria dada ainda hoje a poesia, ainda hoje a reflexão, ainda hoje a filosofia. Quem estará 
por cima dela e lançará a primeira pedra? Hoje, chegou-se a considerar um ato normal o lançar pedras, invectivas, bombas. Quem critica hoje deve também saber plantar flores. E, se for preciso, lançá-las. Esse seria o maior ato de poder.

3.

Detenho-me um momento neste ponto: talvez tenham dito que eu tentei eludir retoricamente o assunto da relação intelectual-poder em Cuba? Conheço a censura e outros recursos da terapia política. Não podem dissuadir o poeta que entregou a sua energia a perseguir um estado superior de consciência. Não é culpa nem privilégio de sistema algum ter convertido o poeta em refém da realidade. Ainda quando todos os sistemas, por sua própria condição de sistemas, tenham atribuído em algum momento o perigoso mérito de ter subjugado a natureza toda e, por tal, a natureza humana e a raiz da poesia. Em realidade, foi o poeta quem, em seu impulso mais puro e nos quatro pontos cardeais, decidiu permanecer, cantando, entre os homens; essa força de sua escolha é o que o fez subsistir até hoje entre os perseguidos e os silenciados, aqueles que veremos o sol sair do outro lado da montanha amanhã.

4.

Saio para caminhar; já sei, a cidade devastada que todos viram nas páginas de Le Monde Diplomatique e em Buena Vista Social Club de Wim Wenders. Deixo meu filho na porta de uma escola reformada, um antigo armazém de bens apreendidos pelo Estado. Segundo o qual o futuro do meu filho está garantido. Segundo o meu instinto de pai e de poeta, seu presente não é menos incerto que o de todos os habitantes deste planeta em ebulição, nosso vulcão de cada dia. O preço do noni, a fruta prodigiosa que, segundo dizem, possui 101 propriedades curativas, é de 5 pesos por unidade no mercado estatal e de 7 na tenda do verdureiro. As garotas com as quais tropeço pelo caminho são tão vivazes como de costume, como "perlas preciosas, adorno de ilusión..."; no Malecón, uma típica estampa do socialismo latino: um homem, sob o mando da escavadora, trabalha, e 19 homens o observam. Não são curiosos, são pedreiros e chefes de obra: esses gesticulam dando ordens, aqueles permanecem absortos em contemplação. Um inclusive se apoiou no muro, reclina a cabeça na perna de um colega e fuma. Marx e Lafargue, padre e genro eternamente conciliados: o direito ao trabalho e o direito à preguiça em unidade dialética.

Por outro lado, aqueles que desde os think tanks do Ocidente cristãomaterialista determinaram que Cuba seja um país pobre professam não só um materialismo dissimulado e fundamentalista, mas também uma visão limitada e, por sua vez, pobre da matéria-espírito em desenvolvimento e movimento. 
Porque a matéria-espírito não é só objeto, sua liberdade não é só arbítrio e sua realização não é só gratificação.

5.

Quem disse que todo o real era racional, um ideólogo a serviço de um partido ou um poeta a serviço da publicidade? Na propaganda para o uso da sociedade do capital prima o chamado a um carpe diem individualista: be yourself. $\mathrm{E}$, inclusive, segundo observo em uma mureta no aeroporto de Amsterdam, be a tiger. Não deixe que outros consumam por você, aqui e agora consuma qualquer coisa, mas consuma VOCÊ. Na sociedade mais austera que nos coube aos cubanos viver, a propaganda tenta ativar outras regiões da consciência. Verbigratia: as ideias não podem ser derrotadas, as ideias são imortais etc. Platón dixit, Marx dixit. Há, ademais, uma palavra na qual coincidem a propaganda mercantil e a política: revolução. E outra ainda na qual desembocam todas as mensagens e valores ideológicos, econômicos, místicos e luxuosos: energia. Mistério supremo de nossa irrealidade.

Como indivíduo, como poeta e, no sentido helênico, como idiota, vejo a ambos os chamados como simpáticos e estimulantes. Cheios de graça, vazios de sentido. Graça e sentido; encontra-se aqui um dos pontos de guinada nos quais o intelectual pode atuar frente ao poder e no seio social. Proponho combinações:

Be yourself, las ideas son inmortales.

Sabe-se que para dialogar com o poder de maneira direta são necessárias melhores ferramentas que o engenho verbal e conceitual que subjaz toda poesia filosófica e que, no fim das contas, não nos falta nem trabalho nem matéria-prima: como voltar a encher de sentido essas duplas, se não de contrários, sim de malcuidados conceitos que herdamos de nossa civilização decomposta: messianismo e produtividade, poupança e dignidade, futuro e morte, honestidade e democracia, revolução e consumo. Revolução: hoje te nomeiam em comerciais nas quatro esquinas do mundo, aleluia! ! 


\section{CORPO, SOMBRA, UMBRAL ${ }^{3}$}

Um indivíduo, ao avançar temerosamente por um sendeiro aparentemente pouco frequentado, sente em suas costas a proximidade de outro corpo que se acerca por cima com uma velocidade tal que não lhe deixa tempo, não para virar-se e observá-lo, sequer para reconhecê-lo, uma vez que esse corpo o ultrapassou. Contudo, em um gesto instintivo, quem sabe se esquivando ou num impulso, conseguiu roçá-lo e em sua mão ficou por um instante o rastro iridescente desse encontro. Em sua dimensão originária, a poesia é esse gesto e seu rastro, a escritura poética, a precária descrição de ambos.

Em sua compostura numinosa, o corpo que cobre concede ao corpo coberto a possibilidade de uma manifestação na qual se reúnem, como se fosse pela primeira vez, a alegria do maleável e a rigidez do hierático, a liberação e a angústia, o jogo e a oração. A princípio, o desconhecido nos fará rir e reagir ao mesmo tempo, e nesse instante a nostalgia alcança a sua incandescência máxima e a plenitude, o seu momento mais vertiginoso: a poesia é uma piada trêmula.

Poderia ser dito que o apontar com demasiado entusiasmo para uma condição física mais bem do que para uma condição espiritual da poesia gostaria de circunscrevê-la ao senhorio do corpo, levá-la com força ao domínio de outras técnicas que pareceriam excêntricas com respeito àquelas da escritura, vê-la diminuída pelo transe de uma meditação irreproduzível ou, por assim dizer, de uma "arte marcial".

O teatro nos lembra aquilo que de ato - e certamente de ato marcial - tem a poesia. Natureza e poder criativo vão de mãos dadas quando, pela arte do ator, o fogo que consome o individual ilumina a humanidade. Martí fala sobre a "estrela que ilumina e mata", Craig professa a equação do ator "mais fogo, menos egoísmo", Shakespeare diz que o céu faz conosco o que fazemos com as tochas que "não se acendem para si mesmas". Na intensidade do desapego que a constitui, a operação poética não está longe do riken no ken que propõe o tratado de Zeami: "o olho do ator que se vê a si mesmo à distância".

$\mathrm{Na}$ busca de um espaço propício para o seu florescimento, no equilíbrio entre a tensão e o relaxamento em que se desenvolve, em sua submissão aos imperativos da concentração, a escritura poética deixa entrever a sua agonia, logo também a sua agonística, e unicamente nesses combates o "homem de letras" e o "homem de armas" vêm a ser a mesma coisa; em tais encontros, ainda quando a supremacia do literário, compulsão pela letra, contribua a 
fazê-la esquecer, dissipam-se assuntos que vão além da escritura mesma e sua aplicabilidade.

A desmesurada celebração que a cultura faz do mundo escrito a despeito daquilo que o antecede, e ultrapassa, fez com que passemos por alto o seu caráter impermanente; Quem deixa óbvio o fato de que o poema é apenas a descrição termina por oferecer com pretensão ontológica à descrição de descrições anteriores: ou seja, a literatura. Dessa ontologia de uma escritura alienada de seu momento originário à paixão linguística ou filosófica, não há muita distância.

As disposições classificatórias, que são tão mais arbitrárias quanto com mais esforço aspiram à precisão, e que em algum momento pareceram, em sua brutal aceitação da competitividade, ser típicas da "cultura de massas", fazemse notar agora com energia excepcional no proceder da "alta cultura": com as tipologias, com as vanguardas, com a hiperinflação da filosofia que está em todas as partes menos ali onde são requeridas, com as condecorações e os curricula, a cultura se entrega ao afã da distinção; segundo esta, diferença e novidade se unem para certificar a autenticidade, e a autenticidade seria então um sinônimo do superior, sempre que possa ser submetido à interpretação e à mercantilização. Daí que a poesia, incluída na literatura, tenha passado, por uma parte, a ser um componente que a cultura pode desbordar em doses prudenciais em outros compartimentos como a cibernética ou a publicidade ou, por outra parte, um composto estético sujeito à reprodução em forma de artefato ontológico: o livro. Não deve soar estranho se a poesia se ausenta do objeto que deve legitimá-la: frente à interpretação do "inefável" e à reprodução mecânica do "único", ela evita os seus próprios documentos.

Na peculiar conjunção das perguntas "quem" ou o "que eu sou?" e na obediência às regras do jogo escritural, o poema cria a sua pessoa. Dado que essa conjunção depende da "presença de ânimo" de um sujeito simulador que busca uma coisa enquanto finge se ocupar de outra, deve-se falar da natureza disjuntiva do momento poético, de sua dimensão teatral, sua ironia sincera. Dessas significações do ato da escritura há muito a se investigar. Artaud tinha o costume de levar a cabo o seu ato, batendo em uma fenda com uma faca ou, segundo o caso, com um martelo, enquanto aplicava o seu "sistema de respiração e cantoria". Cantoria que é ocioso reproduzir aqui, pois o próprio ator avisou que não servia de nada se não era lançada de golpe, escrita assim não diz nada e não é senão cinza.

A pretensão de pôr em escrito aquilo que só pode ser atuado pode chegar a ser exagerada se a escritura não é efetuada em sua ambivalência de redação e representação, se nela "ata" e "ato" não se reencontram nas origens; daí a radicalidade do transe, daí a gravidez que comporta o dar por fato o sempre incriado: escreve-se a poesia não porque alguém seja poeta, mas para aspirar a sê-lo. 
Porém, uma vez que a escritura tenha deposto sua declaração, o sedimento do poema fixará o seu destino ao mesmo tempo que escurecerá a sua procedência: aberto, sim, à interpretação que tenta reanimá-lo somente desde a letra, o poema mostra em realidade um umbral intransponível, como lembrava um alquimista, "o queijo não pode voltar a ser leite".

Não será a interpretação, mas a representação aquela que pode dissolver o mundo escrito; na mediação do ator-poeta, ativa-se a memória de um corpo impessoal, o sinal de partida para essa visão que leva do dito ao feito. $\mathrm{Na}$ interdependência atual de corpo e pensamento, um pensamento sem tempo é despertado.

Posto que a escritura é uma personificação, ela leva consigo o gérmen do impessoal que a antecedeu, seja no mundo dos sentidos, seja na condição profética, o poeta efetiva aquilo que não é, amplifica e tece; relaciona-se. Mattewame é a voz huichol que qualifica esse instante do poeta: "o que não sabe e vai saber".

A poesia se separa do propósito, às vezes brusca, às vezes imperceptivelmente, sai do discurso da objetivação, como quem, prescindindo de atributos, suspendendo o compromisso com as circunstâncias e esquivando a compulsão do futuro, gostaria de atuar menos e dizer menos do que é sabido para representar aquilo que não se sabe.

Se o objeto poético é, em realidade, a sombra que a poesia fez projetarse ao redator, então observaremos sob uma luz diferente a situação em que a Cultura a acomodou, perceberemos a superstição literária e as suas imagens: livro e receptor, autor e circunstância. Quando é percebido o construído em seus cimentos, a poesia prescinde de seus simplificadores; o poeta, de seu álibi.

A comunhão supersticiosa com o social requer do poeta que ele carregue suas tarefas ao terreno cada vez mais vago da utilidade, uma vez instaurado o culto da circunstancialidade, os especialistas em redação estão sujeitos à prática das opiniões, essas mesmas opiniões que nunca chegam ao ponto; o poeta participa de tudo com um tal de não participar de nada, estuda filosofias e expõe a sua personalidade nas reservas culturais. Quando o pan-esteticismo inerente à modernidade ditou que a poesia pode ser encontrada em todas as partes, esqueceram de acrescentar que não se deixaria ver ali onde é mencionada com interesses.

Para a percepção da poesia e para a sua emanação, a escritura poderia dispor, com a licença do mestre Eckhart, de um instrumental místico: uma cumbuca de água, o sol e um espelho. Na massa de água que contém o espelho, o sol se apresenta em uma manifestação dupla: energia projetada e imagem verdadeira, porque, no corpo fecundo do espelho, o sol se reproduziu, sem que por isso, e essa é a maravilha da poesia, nem espelho, nem sol, nem água deixaram de ser o que são. 
O poeta e o herói têm em comum um destino de silêncio. $O$ sujeito de ouvidos persuasivos persegue a pausa na qual todas as linguagens se unificam; por isso, disse Gottfried Benn, "os poetas devem saber calar", ou seja, saber morrer. Não há imagem como a do guerreiro que, na visão de Durero, cavalga em companhia da morte; "eu imito" - disse Artaud - "um guerreiro estupefato, deixado só nas cavernas da terra", e prepara-se para morrer sentado, como um samurai: "disse tudo o que tinha que dizer". Donos no silêncio último da palavra original, o poeta e o herói falam no mutismo de suas ações.

Descrição precisa do país da poesia, "país do espelho", no qual nos olhamos e, através do espelho, olhamos. A Rainha de Copas explica à Alice a essência da ação poética: "você deve correr tudo o que possa para ficar no mesmo lugar".

"Se quiser chegar a outro lugar", acrescenta a Rainha de Copas, "deve correr pelo menos duas vezes mais rápido". Quando a poesia não quer chegar a nenhuma outra parte, a imobilidade é uma ótima velocidade. I

OMAR PÉREZ - Poeta, músico, tradutor e ensaísta residente em Havana, Cuba. Publicou ¿Oiste hablar del gato de pelea? (1999), La perseverancia de un hombre oscuro (2000 - Premio Nacional de la Crítica), Canciones y letanías (2002), Língua franca (2009), Crítica de la razón puta (2010 - Premio de Poesía Nicolás Guillén), El corazón mediterráneo (2010), Word (CD, 2009), Cubanología (CD, 2015), Tablet A (2015), Filantropical (2016) e Veneno o del hábito del prejuicio (2019). Além de diversos textos e traduções publicados em distintos livros e revistas, foi um dos fundadores do grupo de intervenção cultural Proyecto Paideia (1988-1990) e editor da revista La Naranja Dulce (1989-1990). 